\title{
Topical collection of the Triple Helix Journal: agents of change in university- industry-government-society relationships
}

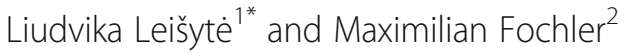

\author{
* Correspondence: \\ liudvika.leisyte@tu-dortmund.de \\ ${ }^{1}$ Center for Higher Education \\ Faculty of Management and \\ Economics TU Dortmund University, \\ Dortmund, Germany \\ Full list of author information is \\ available at the end of the article
}

University-industry-government collaborations and relationships-as theorized by the Triple Helix model (Etzkowitz, and Zhou, 2018) among others-have been analyzed in a plethora of innovation, higher education and STS studies. Most of these studies have focused on national, regional, and institutional levels, examining the structures of interaction as well as the formal and informal linkages created in collaborations. More recent elaborations of the Triple Helix model have also pointed to the importance of society and societal actors beyond those institutionalized in universities, industry, and government. They emphasize the importance of integrating a perspective on the role of the media, publics, and civil society actors to understand innovation in knowledge economies. In recent debates, the concept of responsible research and innovation broadens the range of potential actors in innovation (Stilgoe et al. 2013, von Schomberg 2013). This asks for a deeper understanding of the characteristics of these actors as well as of the mechanisms by which they exert influence over institutional development.

On the levels of organizations and organizational fields, existing literature on university-industry-government-society relationships has focused on the creation and institutionalization of technology transfer structures. A range of studies have explored the role of governments in setting up policies to facilitate interaction between university and industry, such as patenting regulation or sectoral policies for biotechnology or nanotechnology. The role of funding agencies promoting the interaction between university and industry has merited attention and has increased our understanding of the potentials and limitations of specific funding mechanisms. Significant work has emphasized the role of venture capitalists in promoting academic entrepreneurship. However, despite this plethora of studies, we still know very little about the locus and dynamics of agency when it comes to initiating change in university-industry-government-society interactions in innovation processes.

Existing contributions on university-industry-government-society relationships are extremely useful to understand the drivers and processes of innovation in different countries. However, they mostly focus on the demand side, for example on the implementation of innovation policies via structural arrangements. The supply side of the story-the agency of knowledge producers not only in academia, industry, but also government and society—has to some extent been overlooked (Leišytė, 2018; Ranga and Etzkowitz 2013). Even though universities are understood as playing a crucial role

(c) The Author(s). 2018 Open Access This article is distributed under the terms of the Creative Commons Attribution 4.0 International License (http://creativecommons.org/licenses/by/4.0/), which permits unrestricted use, distribution, and reproduction in any medium, provided you give appropriate credit to the original author(s) and the source, provide a link to the Creative Commons license, and indicate if changes were made. 
in innovation, we know very little about the role of key actors who influence and change institutional arrangements in and around universities (Etzkowitz 1997, Ranga and Etzkowitz 2013), e.g., by lobbying governmental actors to change funding regimes and regulation, by engaging in community interaction with civil society or by creating nascent firms and platforms for exchange between various actors in student or academic entrepreneurship.

Here, we turn to the notion of institutional entrepreneurs (DiMaggio, 1988) who effect change in university-industry-government-society interactions using their skills, resources, and capital. We find this concept helpful as it allows for situated understandings of change agents who create or disrupt institutions at different levels: "Institutional change agents may have intended or not to change their institutional environment- but they initiate, and actively participate in the implementation of changes that diverge from existing institutions" (Battilana et al. 2009, p. 70). In this context, understanding the characteristics and strategies of actors and the conditions under which they create new or disrupt existing institutions are of particular interest. In university and other public research organizational settings, scientists, elite academics, charismatic teachers, student representatives as well as managers and leaders at different organizational levels can be important change agents, either as individuals or parts of collectives, e.g., a rectors' association. In industry, serial entrepreneurs, venture capitalists, corporate managers, or chambers of commerce could be examples of possible agents of change. In government, influential politicians at various levels as well as governmental intermediary funding agencies can be seen as important actors in shaping Triple Helix relations. In civil society, we could identify media, opinion leaders, or social movements as some of the possible actors that may reshape institutional arrangements around the helixes.

This topical collection of the Triple Helix addresses the role and types of actors influencing the Triple Helix context. It includes five contributions that approach the wider topic from different angles.

\section{Contributions highlighting macro-meso level agents of change}

Merli Tamtik analyzes the role of intermediary non-governmental stakeholders in the Canadian innovation ecosystem. Her paper examines the role of three selected stakeholders-the Canadian Science Policy Centre, the MaRS Discovery District, and the university vice presidents research-based on a sample of expert interviews with key actors across different levels and sectors of the Canadian innovation system. Her results suggest that these non-governmental stakeholders play an increasing role in the coordination of actors in the Canadian ecosystem, which has previously struggled with tendencies of fragmentation. She identifies different types of cooperation activities the intermediaries engage in and analyses the challenges these intermediaries meet in their coordinative efforts.

Florian Poppen and Reinhold Decker offer a practice-based perspective on intermediaries as institutional entrepreneurs. Drawing on their rich experience in the Bielefeld 2000 plus initiative, they give an account of the potential and challenges of initiatives that aim to do intermediary work between science, economy, public administration, and civil society on a city level. They argue that this specific type of intermediary not only acts both as an institutional entrepreneur itself, but also as a platform for other entrepreneurs which seek to induce institutional change. The conclusions of their paper 
speak to both practitioners interested in establishing related intermediary activities, as well as to the academic debate on the role of intermediaries in Triple Helix constellations.

\section{Contributions highlighting micro-level agents of change (individual, group, center)}

Liudvika Leišyte and Lisa Sigl address the individual level of actors- scientific entrepreneurs and research managers in the context of the German state North Rhine-Westphalia. Their contribution "Academic institutional entrepreneurs in Germany. Navigating and shaping multi-level research commercialization governance" shows that that trust in scientific entrepreneurs from research managers, their scientific standing and leadership, as well as the type of academic entrepreneurship are central in shaping the Triple Helix relationships. The authors identify two types of agency exerted to shape the Triple Helix context-bricolage and institutional entrepreneurship.

Maximilian Fochler has studied how narrative learning processes among company founders relate to how academia-industry-government relations are shaped in a particular region. Drawing on biographical interviews with entrepreneurs and serial entrepreneurs in the Vienna biotechnology cluster, he shows how entrepreneurs learn from stories about past successes and failures in the cluster. His paper points to the complex dynamics of financialization as playing a crucial role in the dynamics of innovation ecosystems in the life sciences. The paper concludes with policy recommendations for cluster management and regional innovation policy.

Siri Borlaug and Magnus Gulbrandsen explore the role of excellence centers in individual researchers' identities and scientific practices in Sweden and Norway. Drawing on institutional logics, they find that engagement in innovation seems common in research oriented centers where the centrality of the innovation logic is low, while they find more tension and dissatisfaction among individuals who work in centers devoted to both science and innovation in emerging fields of research or with weak social ties to their partners. They argue that the effects of the long-term funding of centers of excellence must be understood in the context of disciplinary characteristics and the existing overall funding system in the country.

Authors' contributions

Both authors read and approved the final manuscript.

Competing interests

Both authors declare that they have no competing interests.

Publisher's Note

Springer Nature remains neutral with regard to jurisdictional claims in published maps and institutional affiliations.

Author details

${ }^{1}$ Center for Higher Education Faculty of Management and Economics TU Dortmund University, Dortmund, Germany.

²Department of Science and Technology Studies, University of Vienna, Vienna, Australia.

Battilana J, Leca B, Boxenbaum E (2009) How actors change institutions: towards a theory of institutional entrepreneurship. Acad Manag Ann 3(1):65-107

DiMaggio PJ (1988) Interest and agency in institutional theory. In: Zucker L (ed) Institutional patterns and organizations. Ballinger, Cambridge, pp 3-21 
Etzkowitz H (1997) The Entrepreneurial University and the Emergence of Democratic Corporatism. In: Etzkowitz H, Leydesdorff L (eds) Universities and the Global Knowledge Economy, pp 141-154

Etzkowitz H, Zhou C (2018) The Triple Helix: University-Industry-Government Innovation and Entrepreneurship, 2nd edn. Routledge, London

Leišyte L (2018) Innovation studies in higher education research. In: Teixeira P, Shin J (eds) Encyclopedia of international higher education systems and institutions. Springer, Dordrecht

Ranga M, Etzkowitz H (2013) Triple Helix systems: an analytical framework for innovation policy and practice in the knowledge society. Ind High Educ 27(4):237-262

Stilgoe J, Owen R, Macnaghten P (2013) Developing a framework for responsible innovation. Res Policy 42(9):1568-1580

von Schomberg R (2013) A vision of responsible research and innovation. In: Owen R, Bessant J, Heintz M (eds) Responsible innovation: managing the responsible emergence of science and innovation in Society, pp 51-74

Submit your manuscript to a SpringerOpen ${ }^{\circ}$ journal and benefit from:

- Convenient online submission

- Rigorous peer review

Open access: articles freely available online

High visibility within the field

- Retaining the copyright to your article 